\title{
The Balance Between the Transmitted and the Perceived Image of Luxury Fragrance Brands
}

\author{
Mónica Díaz-Bustamante, Sonia Carcelén, Maria Puelles \\ Complutense University of Madrid, Madrid, Spain
}

\begin{abstract}
The luxury market has experienced considerable growth over recent years, being one of the sectors that have been the most resistant to the current economic recession. Selective fragrances make up one of the primary categories of the so-called accessible luxury consumed by a middle class that is seeking to approach the upper classes by copying their lifestyle. Despite the importance of this market, there is relatively little literature existing in regards to the study of the image of luxury brands due to the complexity of the luxury phenomenon. This article presents the results of an initial qualitative study conducted on focus groups of luxury fragrance consumers, making it possible to identify the types of attributes to be considered when studying the brand image of said luxury products. Subsequently, a quantitative study was conducted in order to determine the perceived image of the principle luxury fragrance brands by consumers. Thanks to this study, it has been possible to determine the typical profile of each of the analyzed brands so that a subsequent comparison may be made with the advertising created by said brands in order to verify whether or not the image projected in their advertising corresponds with the perceived image of their target audience.
\end{abstract}

Keywords: brand image, luxury, fragrances, advertising, perceptions

\section{Introduction}

There is a great deal of confusion regarding the concept of luxury. A review of the literature presents different meanings, approaches, and positive and negative connotations associated with the concept (Mandeville, 1729, as cited in Smith, 1997; Letichevsky, 2002; Colmeiro, 1863; Braudel, 1979; Veblen, 1899, as cited in Vickers \& Renand, 2003; Lunt \& Livingstone, 1992, as cited in Vickers \& Renand, 2003; Allérès, 1990; Campuzano García, 2007). Based on definitions provided by various authors, it has been concluded that luxury is:

All that is considered to be absolutely necessary or basic within a specific social-economic, historic and cultural context, that, at the same time, provides personal pleasure and social recognition, and that therefore permits the reaffirmation of one’s identity and access to a specific social group and demonstrates it. (Díaz-Bustamante, 2012, p. 62)

Over the past few decades, luxury consumption has experienced spectacular growth, being one of the sectors that have shown the greatest resistance to the economic crisis of recent years: $-8 \%$ in $2009,13 \%$ in 2010, $11 \%$ in 2011, $10 \%$ in 2012, and $2 \%$ in 2013. Sales figures over this past year are estimated to have reached 217 milliards euros (Bain \& Company, 2013).

Mónica Díaz-Bustamante, associate professor, Faculty of Communication, Marketing Department, Complutense University of Madrid. Email: mdiaz-bu@ucm.es.

Sonia Carcelén, Ph.D., contracted professor, Faculty of Communication, Marketing Department, Complutense University of Madrid.

Maria Puelles, Ph.D., contracted professor, Faculty of Business and Administration, Marketing Department, Complutense University of Madrid. 
One of the largest luxury market product categories is that of perfumes and cosmetics, which makes up some $20 \%$ of the market (Bain \& Company, 2013). Perfumes, in particular, is one of the main gateways into the world of luxury consumption, being one of the so-called “affordable luxuries" (Allérès, 1990); therefore, most of the luxury fashion and jewelry brands have included these products in their diversification strategies (Campuzano García, 2007).

However, despite the growing importance of the phenomenon of luxury and the consumption of luxury goods, academic and professional literature around it is quite limited, particularly in the area of research on luxury brands image.

Existing studies on the image of luxury brands have been conducted by measuring only those perceptions of the degree of luxury of the very luxury brands, with each of these relying on earlier versions that modify or increase the dimensions and attributes considered in the evaluation of luxury.

This work focuses on the study of the image of luxury fragrance brands based on contributions made by various authors (D. A. Aaker, 1996; Stern, Zinkhan, \& Jaju, 2001; Wiedmann, Hennigs, \& Siebels, 2007a; 2007b; 2009; Ambroise \& Valette-Florence, 2010; Kotler \& Keller, 2012).

\section{Literature Review}

\section{Brand Image}

There is no widely accepted single definition of the brand image concept. Dichter (1985) defined brand image as the overall impression produced by the brand in the mind of the consumer. Dobni and Zinkhan (1990) referred to it as the set of emotional and rational perceptions that consumers associate with each brand. D. A. Aaker (1996), Keller (1998), and Kotler and Keller (2012) discussed consumer brand perceptions and beliefs based on memories, and they believed that these perceptions are multi-dimensional.

Numerous authors agree with this multi-dimensional nature of the brand image. For instance, Stern et al. (2001), who preferred to use the term "marketing image” rather than "brand image”, grouped together different perspectives of image for study, such as product, organization, symbol, individual, sales establishment, and so on. Cerviño Fernández (2002) believed that brand image focuses on the way in which consumers view the brand and how they perceive and decode information released by these brands on their products, services, communications, logotypes, and so on. Hsieh (2002) linked the dimensions of brand image with consumer needs. Koubaa (2008) highlighted how the consumer's country of origin has a significant influence on brand perception. Ambroise and Valette-Florence (2010) believed that brand personality has the primary function of offering uniqueness to the brand.

However, based on this multi-dimensional brand image perspective, no standardized and universally accepted methodology has been established that would allow for the image measurement in any activity market or sector (Low \& Lamb, 2000; Stern et al., 2001). This raises three issues:

(1) Agreement has yet to be reached regarding the relevance of qualitative or quantitative techniques. While some authors have defended the use of the former (Gardner \& Levy, 1955; Durgee \& Stuart, 1987; Danes, Hess, Story, \& Vorst, 2012), others have opted for the latter, and the majority of authors have suggested the use of mixed techniques for image studies, combining qualitative and quantitative tools during the different study phases (Churchill, 1979; Zaichkowsky, 1985; Sanz de la Tajada, 1994; Low \& Lamb, 2000; Del Rio, Vazquez, \& Iglesias, 2001; Martinez \& De Chernatony, 2004; Dolnicar \& Grün, 2007; Koubaa, 2008; Park, 2009; Huang, 2010); 
(2) Although there are scales that allow for the measurement of partial dimensions of brand image, there is yet to be an agreement on a standard set of attributes; that is, items to be included in a scale for measuring the overall image of any type of brand, regardless of the specific brand product category;

(3) Dobni and Zinkhan (1990) summed up the process that is typically followed when studying brand image using combined qualitative and quantitative instruments. Once again, the lack of agreement as to a specific technique and measurement scale is evident.

\section{Luxury Brands Image}

Literature related to luxury brands image is quite limited, and the studies developed for its study have been restricted to measuring only the perceptions of the brand itself based on the degree of the luxury. Each of these studies relies on existing studies, expanding upon the information that they have provided.

Kapferer (1998) identified 18 attributes-items to measure the degree of luxury associated with these luxury brands. Dubois, Laurent, and Czellar (2001) extended this to 20 attributes that were similar to the 20 proposed by Vigneron and Johnson (2004), who also grouped these into five luxury factors (conspicuousness, uniqueness, quality, hedonism, and extended self). Wiedmann et al. (2007a; 2007b; 2009) established that the perceptions of the value of brand luxury are based on four interrelated dimensions (financial, functional, individual, and social) grouped into 10 factors (usability, quality, uniqueness, self-identity, hedonic self-gift giving, hedonic extravagance, hedonic self-directed pleasure, hedonic life enrichment, materialistic, prestige), which themselves consist of a total of 48 attributes or semantic items. Godey, Lagier, and Pederzoli (2009) introduced and validated a measurement scale of aesthetic styles applied to luxury goods stores, and finally, Ciornea, Pop, Bacila, and Drule (Tîrca) (2011) added to the Wiedmann, Hennings, and Siebels' studies, considering that luxury is characterized by a set of 11 values.

Despite the interest shown in the existing studies, certain limitations have been found:

(1) None is operational from a point of view of studying the positioning of competitor brands. The brands that have been used in the different studies belong to distinct activity sectors. And while positioning refers to the relative state of a brand in comparison to other competitors, little information is offered to said brand if the knowledge of the state of other brands does not refer to direct competitors;

(2) All of the studies analyze only perceptions regarding the degree of luxury of the brands, but do not consider other equally important perceptions related to other brand dimensions (such as those linked to personality, the organization that offers them, the product category to which they belong, etc.);

(3) As the authors of these studies suggest, the items used are only valid in a specific cultural and geographic context. Therefore, in order to guarantee the appropriateness and comprehension of the study, the corresponding semantic items should be generated, enunciated, and validated in whichever context the model is to be used.

\section{Objective and Methodology}

Based on the concept of brand image as defined by Kotler and Keller (2012), the principal objective of this study is to study luxury fragrance brand image in Spain including the contributions made by various authors in order to overcome the previously mentioned study limitations. 
Thus, this study considers both the dimension of luxury of the brands being studied in accordance with the work of Wiedmann et al. (2007a; 2007b; 2009), and the dimensions proposed by D. A. Aaker (1996) regarding brand like a product, an organization, a person, and a symbol. Furthermore, all the brands studied here belong to the same sector and compete with one another (they are luxury fragrance brands of the Spanish market). In addition, the attributes of the brands studied have been generated, enunciated, and validated in Spain, where the proposed study has been applied.

To apply the study used to analyze its image, the product category chosen was luxury fragrances. This was based on the importance of this category in the global luxury market (Bain \& Company, 2013), and its widespread availability for purchase and use as an accessible luxury product (Allérès, 1990; Campuzano García, 2007). It was also based on data from Stanpa 2013 (Spanish Cosmetic Toiletry and Perfumery Association), which revealed the significance of luxury fragrances in the Spanish market of select perfumery and cosmetics (62\%) and in the total Spanish fragrance market (73\%). Finally, it was also selected based on the growth registered by the specific luxury fragrance market in Spain which, according to data from European forecasts, was over 120\% from 1997 to 2011. This emphasizes the strong penetration rate of this luxury product in the Spanish population.

The methodology used in this study was based on a process defined by Dobni and Zinkhan (1990) for the study of brand image using a combination of qualitative and quantitative techniques; this process has been accepted and used by many authors (among others: Joyce, 1963; Sanz de la Tajada, 1994; Low \& Lamb, 2000; Del Rio et al., 2001; Koubaa, 2008).

Therefore, in the initial qualitative phase of the study, six focus groups were conducted, in which 35 luxury-fragrance consumers in Spain participated (distributed between men and women, and grouped by age: between 18 and 29, 30 and 44, and 45 and older), and were selected using the snowball sampling method. This phase allowed for the comparison of the existence of the five proposed dimensions linked to the image of the luxury fragrance brand, and for determination of the basic criteria used in purchase decision-making and consumption of the product purchased. It focused on attributes of image, stating them as items in precise and easily understood terms for Spanish consumers.

The results of this phase were reviewed with professional experts from the Spanish perfume-sector (distributors and manufacturers), resulting in a reduction of the 33 initial image attributes to 21 definitive attributes, with their corresponding semantic items. In addition, the final brands to be studied were selected, based on the ranking of the main brands of the Spanish luxury-fragrance market (European Forecasts 2008-2011): Chanel, Calvin Klein, Armani, Dior, Loewe, Paco Rabanne, Jean Paul Gaultier, and Hugo Boss.

The second quantitative phase was carried out using a structured individual survey (see the data sheet in Table 1).

In this phase, a 7-point differential semantic scale was used to measure the image of relevant brands. This scale was created based on the attribute-items identified in the previous phase, some of which were similar to others that had already been validated in academic literature for the measurement of perceived brand quality (Keller \& D. A. Aaker, 1992), as well as the attitude towards the brand (Zinkhan, Locander, \& Leigh, 1986), its personality (J. L. Aaker, 1997), or its degree of luxury (Wiedmann et al., 2007a; 2007b; 2009). The reliability of the scale was evaluated using Cronbach's alpha for the different dimensions of the considered image. 
Table 1

Data Sheet From the Survey Carried Out

\begin{tabular}{|c|c|c|}
\hline & Questionnaire & Structured - 305 variables \\
\hline Universe & \multicolumn{2}{|c|}{$\begin{array}{l}\text { People at } 18 \text { years old, from medium and upper class, luxury fragrances consumers, } \\
\text { and living in Madrid }\end{array}$} \\
\hline Competitive structure & \multicolumn{2}{|c|}{$\begin{array}{l}\text { Main brands of Spanish market of luxury fragrances: Chanel, Calvin Klein, Armani, } \\
\text { Dior, Loewe, Paco Rabanne, Boss, Jean Paul Gaultier }\end{array}$} \\
\hline \multirow{5}{*}{ Sampling } & Sample size & 520 people \\
\hline & Sampling error & $4 \%$ \\
\hline & Dispersion & $\rho=0.5$ \\
\hline & Confidence level & $95.5 \%$ \\
\hline & Sampling method & $\begin{array}{l}\text { Non-random quotas sampling (according } \\
\text { to sex and age) by simple allocation }\end{array}$ \\
\hline \multirow{2}{*}{ Field work } & Period & June-13 \\
\hline & Place & Households and work centers \\
\hline \multirow{5}{*}{ Data analysis } & \multirow{4}{*}{ Statistical techniques } & Simple and cross TAB \\
\hline & & Cluster analysis \\
\hline & & Principal components analysis \\
\hline & & Correspondence factor analysis \\
\hline & Software & DYANE - Version 4 Excel \\
\hline
\end{tabular}

Note. Source: Prepared by the authors.

\section{Results}

\section{Qualitative Phase}

Initially, 33 image attributes were identified, together with their semantic items, for luxury fragrance brands. After review by experts of the Spanish perfume and cosmetics sector, the number of these attributes was eventually reduced to 21, grouped into five categories linked to the dimensions of the brand image. These categories were: luxury brand attributes, brand personality attributes, fragrance brand attributes, organizational brand attributes, and symbolic brand attributes (see Table 2).

Luxury brand attributes. Many of the identified attributes were found to relate to the degree of luxury attributed to the brands, specifically the following: (1) price: the higher the price, the more luxurious the fragrance; (2) packaging: the more luxurious the packaging, the more luxurious the fragrance; (3) link to a prestigious designer or creator: the higher the renown of the designer or creator of the fragrance, the greater the perception of luxury attributed to the fragrance; (4) belonging to a brand that is already considered to be luxurious: creating another product of the same brand results in it automatically being considered luxurious and, therefore, the more luxurious the brand, the more luxurious it will be considered; (5) exclusivity: the fewer the people who use the fragrance, the more luxurious it is considered to be; and (6) the fragrance's ability to seduce: the greater this seduction ability, the more luxurious the fragrance.

These attributes directly relate to the values of luxury as suggested by Wiedmann et al. (2007a; 2007b; 2009), for use, uniqueness, quality, identity reaffirmation, materialism, hedonism, and prestige in social groups and networks.

Brand personality attributes. All participants agreed that the luxury-fragrance brand should project a personality in accordance with their own, and in line with their lifestyle. For many, it should also be in line with their age. Thus, they indicated that brand correspondence to their style, personality, and age were evaluation 
attributes of the luxury fragrance image and that the brand should also project specific traits that are typically linked to individuals or lifestyles. Among the latter, the following are of special note: femininity, masculinity, youth, maturity, formality, informality, modernity, classicism, romanticism, sophistication, and naturalness (all of which are mentioned by J. L. Aaker, 1997).

Fragrance brand attributes. Regarding this point, participants alluded to the benefits offered by the fragrances themselves, as well as those that also create the corresponding brand image.

As functional benefits of the fragrances, they indicate those that are linked to an intense or fresh quality, the heaviness or lightness of the fragrance itself, and its long or short duration.

Emotional benefits of the fragrance include links to its originality, which is of special importance, and the personal enjoyment offered by its consumption.

Organizational brand attributes. In all of the focus groups, history of the organization, experience and tradition in perfume-making was considered to be a collective brand image attribute.

Another factor mentioned by the majority of the participants as a brand evaluation attribute was the degree of brand knowledge, based on geographic location (local, national, or international). Thus, a national brand will be more well-known than a local one, and an international brand will be better known than a national one. Therefore, the more well known the brand, the greater its degree of development and the greater the importance of the brand's own organization.

Symbolic brand attributes. In this case, it was verified that the evaluation of the luxury-fragrance brands was carried out while considering whether or not the brand's advertising reflected a world of luxury, that is, if it allowed participants to strengthen its identity as luxury symbols.

Furthermore, participants also recognized the influence of advertising pressure carried out by the luxury-fragrance brands in order to facilitate their recognition and improve their memory.

Table 2

Brand Image Attributes-Items for Luxury Fragrances

\begin{tabular}{|l|l|l|}
\hline Attributes-items & & Cronbach's alpha \\
\hline Luxury brand attributes & $\begin{array}{l}\text { Its price is/is not accessible } \\
\text { Its packaging is/is not luxurious } \\
\text { The brand is/is not linked to a prestigious designer or creator } \\
\text { It is/is not a top luxury brand } \\
\text { Their fragrances are used by many/few people } \\
\text { Their fragrances are very/not very seductive }\end{array}$ & $\alpha=0.682$ \\
\hline Brand personality attributes & $\begin{array}{l}\text { It is a brand that does/does not correspond to my style and personality } \\
\text { It is feminine/masculine } \\
\text { It is young/mature } \\
\text { It reflects a formal/an informal style } \\
\text { It is a classic/modern brand } \\
\text { It is sophisticated/natural } \\
\text { It is/is not romantic }\end{array}$ & $\alpha=0.768$ \\
\hline Fragrance brand attributes & $\begin{array}{l}\text { Their fragrances are fresh and light/intense and heavy } \\
\text { Their fragrances are very/not very long-lasting } \\
\text { Their fragrances are/are not original }\end{array}$ & $\alpha=0.703$ \\
\hline Organizational brand attributes & $\begin{array}{l}\text { It is a well-known/not a well-known brand } \\
\text { It has/does not have a strong tradition in perfume-making }\end{array}$ & $\alpha=0.828$ \\
\hline Symbolic brand attributes & $\begin{array}{l}\text { Its advertising reflects/does not reflect a world of luxury } \\
\text { They do a lot/little advertising }\end{array}$ & $\alpha=0.564$ \\
\hline
\end{tabular}

Note. Source: Prepared by the authors. 


\section{Quantitative Phase}

Based on the attributes and semantic items identified in the prior phase (see Table 2), a 7-point differential semantic scale was constructed (with a total Cronbach's alpha of 0.87 ), including five subscales, in order to measure the corresponding dimensions of the luxury-fragrance brand image.

In the subsequent analysis, we studied the typical profile of the different brands in order to determine if they correspond with the image presented in the graphic advertising created by said brands.

In Figure 1, it is possible to see the typical profile of each of the luxury fragrance brands that was examined. Below, we present the results of a detailed analysis of the perceived image of each of the brands, based on the criteria type that is extracted from the qualitative phase.

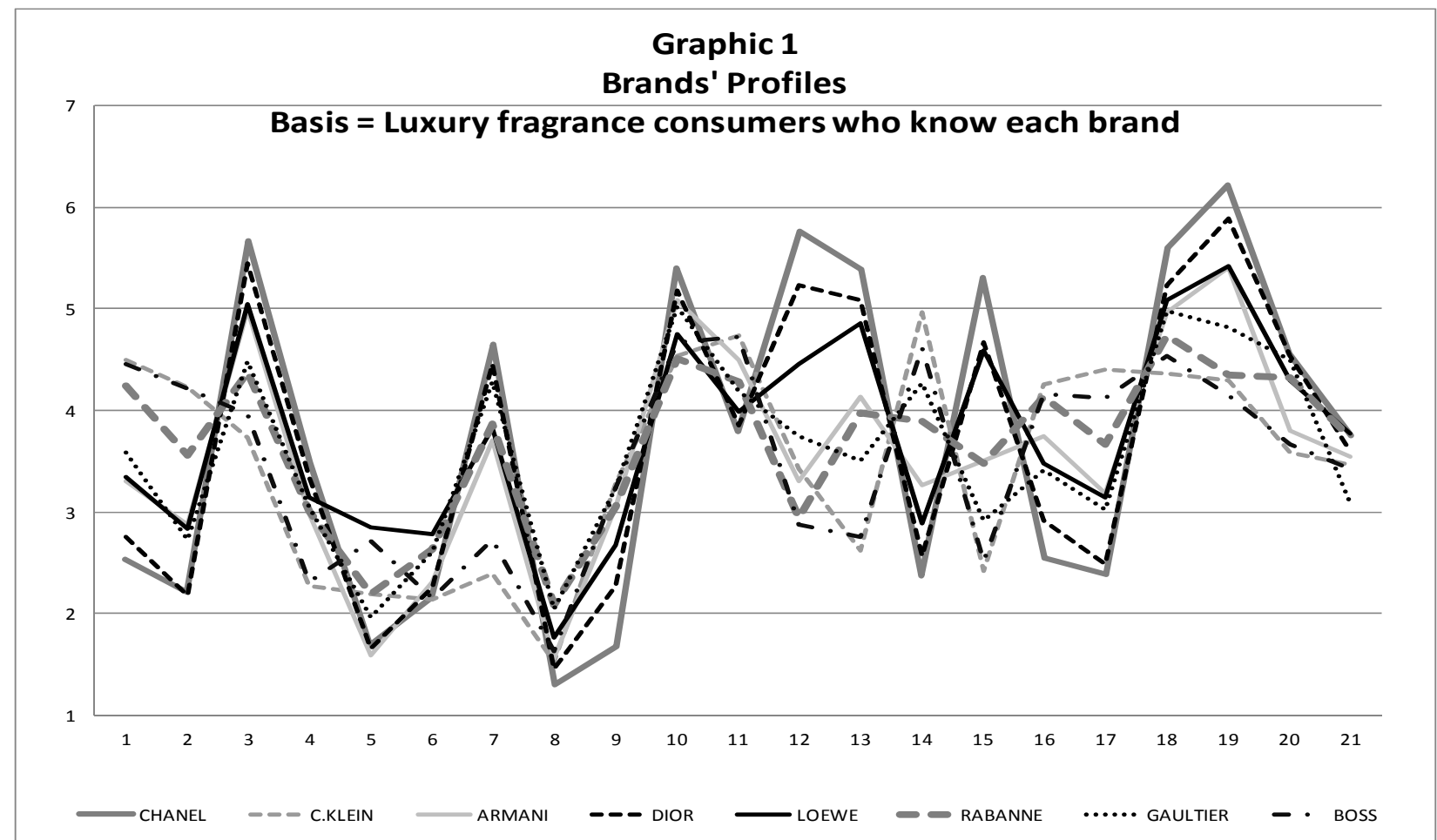

Figure 1. Brands' profiles (Basis = Luxury fragrance consumers who know each brand). Source: Prepared by the authors. Notes. 1. Its price is/is not accessible; 2. Its packaging is/is not luxurious; 3. Its advertising does not reflect/reflects a world of luxury; 4 . Their fragrances are used by many/few people; 5 . The brand is/is not linked to a prestigious designer or creator; 6. They do a lot/little advertising; 7. Their fragrances are fresh and light/intense and heavy; 8. It is a well-known/not a well-known brand; 9. It has/does not have a strong tradition in perfume-making; 10. Their fragrances are very/not very seductive; 11 . This brand does/does not correspond to my age; 12 . It is masculine/feminine; 13. It is young/mature; 14. It reflects a formal/an informal style; 15. It is a modern/classic brand; 16. It is/is not romantic; 17. It is sophisticated/natural; 18. Their fragrances are very/not very long-lasting; 19. It is not/is a top luxury brand; 20. It is a brand that does/does not correspond to my style and personality; 21. Their fragrances are/are not original.

Chanel. To start, there is Chanel, perceived as a very well-known brand, doing a considerable amount of advertising and reflected in large part in the luxury world, strongly linked to a prestigious designer, with a great deal of tradition in perfume creation, situated at the very top of the luxury world, quite feminine and sophisticated, somewhat mature and romantic, having a classic and formal style, which does not overly correspond with the age, style, and personality of the surveyed individual, having a somewhat inaccessible 
price and with somewhat intense and heavy fragrances that are seductive and long-lasting, somewhat original, with quite luxurious packaging and that is not used by too many people.

Furthermore, women perceive the brand as being more feminine, romantic, and sophisticated than men; they also perceive it as being more luxurious and adapted to their age, style, and personality and finally, they perceive its fragrances as being more intense, heavy, seductive, and long-lasting than men.

Regarding age, it is found that as the age decreases, the brand is perceived to be less appropriate for the age, style, and personality of the surveyed individual and it is perceived as more luxurious and with a more inaccessible price.

Calvin Klein. As for Calvin Klein, this brand is perceived quite differently; while it is a very well-known brand that engages in considerable advertising, it is barely reflected in the world of luxury, is closely linked to a prestigious designer, has little tradition in the world of perfume creation, is not situated at the top of the luxury world, is slightly masculine and informal, quite young and modern, corresponds slightly with the age, style, and personality of the surveyed individual, is somewhat accessible in price and has fragrances that are fresh and light, somewhat seductive, long-lasting, and original, has packaging that is not luxurious, and is used by a large number of people.

Regarding the gender of the surveyed individual, it is found that women perceive the brand as being a bit less masculine and a bit more sophisticated than men do, and they also perceive the fragrances as being fresher and lighter.

As for age, it is found that as age increases, the brand is perceived as having less of a tradition in perfume-making, to being less suited to the age, style, and personality of the surveyed individual, and is less well known and youthful and used by fewer individuals.

Armani. As for Armani, this brand is perceived as being very well known, engaging in a considerable amount of advertising and being reflected only slightly in the world of luxury. It is perceived as being very connected to a prestigious designer, as not having much of a tradition in perfume creation, situated somewhat at the top of the luxury world, a bit masculine, modern, informal, romantic, and sophisticated, corresponding somewhat with the age, style, and personality of the surveyed individual, having a price that is somewhat inaccessible and with fragrances that are slightly fresh, light, seductive, long-lasting, and original, having containers that are somewhat luxurious, and being used by a large number of people, but not by too many.

Regarding the gender of the surveyed individual, it was found that women perceive the brand to be somewhat less masculine than men do and they believe that the fragrances are significantly more long-lasting.

As for age, it is found that the younger the individuals, the more they tend to consider that the advertising of the brand reflects the world of luxury more and more, perceiving the brand to be more sophisticated and more situated at the top of the luxury world.

Dior. As for Dior, this brand is perceived as being very well known, engaging in considerable advertising and that is adequately reflected in the world of luxury. It is very closely linked to a prestigious designer, with a considerable tradition in creating perfumes, situated at the very top of the luxury world, slightly feminine, mature, and romantic with a classic and formal touch, quite sophisticated, not corresponding well with the age, style, and personality of the surveyed individual, having a price that is somewhat inaccessible and with fragrances that are somewhat intense and heavy, somewhat seductive, long-lasting, and original, having packaging that is quite luxurious and that is used by a large number of people, but not by too many. 
Furthermore, it should be noted that women perceive the brand to be more feminine, sophisticated, romantic, well known, and adapted to their age than men; they also perceive the fragrances to be more intense, heavy, seductive, long-lasting, expensive and with packaging that is more luxurious than men.

Regarding age, it was found that as the age of the surveyed individual decreases, the brand is considered to be more sophisticated, to be used by fewer people, to be less suitable to the age, style, and personality of the surveyed individual, and to have a price that is more accessible. On the other hand, as the age increases, the perception is that the brand has considerable tradition in perfume-making.

Loewe. As for the brand Loewe, it is perceived as a quite well-known brand, with sufficient advertising and somewhat reflected in the world of luxury, quite connected to a prestigious designer, with somewhat a tradition in perfume-making, situated somewhat near the top of the world of luxury, slightly feminine, mature, classic, and romantic, having a relatively formal style, a bit sophisticated, corresponding only slightly with the age, style, and personality of the surveyed individual, having a price that is somewhat inaccessible and with fragrances that are somewhat fresh, light, seductive, long-lasting, and original, whose packaging is somewhat luxurious and that is used by a number of people, but not by too many.

As for the gender of the surveyed individuals, it is found that women perceive the brand to be more feminine, linked to a prestigious designer, well known, romantic, adapted to their style and personality, and used by more individuals as compared to men; they also believe that the fragrances are fresher, lighter, and more seductive.

Regarding age, it is seen that as the age of the surveyed individuals decreases, the brand is perceived to be less suitable to the age, style, and personality of the individual, more sophisticated, and with a more accessible price.

Paco Rabanne. As for Paco Rabanne, it is perceived as being a quite well-known brand, which engages in a great deal of advertising and is only slightly reflected in the world of luxury. It is linked quite strongly to a prestigious designer, having a bit of tradition in perfume-making, situated at the top of the world of luxury, being very slightly masculine, mature, modern, formal, and sophisticated, corresponding only slightly with the age of the surveyed individuals, but not with their style and personality, having a somewhat accessible price and with fragrances that are a bit fresh, light, seductive, long-lasting, and original, having packaging that is not very luxurious and that is used by a number of people, but not by too many.

As for gender, it should be noted that women consider the brand to be a bit less adapted to their style and personality as compared to men and they perceive their fragrances to be a bit more long-lasting while finding the packages to be more luxurious.

In regards to age, it was found that as the age of the surveyed individuals decreases, an increase was found in the perception of the brand as being modern and the fragrances are perceived to be more seductive and more commonly used.

Jean Paul Gaultier. Regarding Jean Paul Gaultier, this brand is perceived as being quite well known, to engage in a considerable amount of advertising and to be reflected very little in the world of luxury. It is quite strongly linked to a prestigious designer, having little tradition in perfume-making, situated somewhat at the top of the world of luxury, being slightly masculine, youthful, romantic, formal, a bit modern, and sophisticated. It corresponds very slightly with the age, style, and personality of those who were surveyed, having a minimally inaccessible price and with fragrances that are a bit intense, heavy, seductive, long-lasting, and original, with a packaging that is quite luxurious and is used by a number of people, but not by too many. 
As for gender and age differences of the surveyed subjects, first, it is found that women perceive the brand to be somewhat more well known than men, and, second, as the age of the surveyed individuals increases, the brand is considered to be less suitable, less well known, and situated at the top of the luxury world, having less of a tradition in perfume-making and with fragrances that are less seductive and used by fewer number of people.

Boss. As for the last brand that was studied, Boss, it is perceived as being a very well-known brand, engaging in considerable amounts of advertising and that is barely reflected in the world of luxury. It is seen as being linked somewhat to a prestigious designer, with very little tradition in perfume-making, a bit masculine, juvenile, and modern, having a very informal style, corresponds somewhat with the age, style, and personality of the surveyed individuals, having a slightly accessible price and with fragrances that are a bit light and fresh, minimally seductive, long-lasting, and original, with packaging that is neither luxurious nor basic and that is used by a considerable amount of people.

As for the differences based on gender of the surveyed individuals, it should be noted that women perceive this brand as being more informal, less sophisticated, somewhat less masculine, more youthful and with less tradition in perfume-making than men; women also tend to believe that the brand adapts less to their style and personality than men do.

Regarding age, it is noteworthy that as the age decreases, the brand is considered to be more suitable to the age, style, and personality of the surveyed individual, having more tradition in perfume-making, is more well known, sophisticated, and informal and with fragrances that are more seductive, and is believed to be used by more people.

\section{Correspondence Between the Perceived Image of the Luxurious Fragrance Brands and the Image Projected in Their Advertising Campaigns}

In this section, we examine whether or not the perceived image of the studied brands corresponds with the image that is projected in their publicity campaigns.

To do so, we have analyzed the advertising developed by Chanel and Dior (see Figures 2 and 3), since they are the brands that are the most often associated with the world of the women, since they engage in the most frequent "product advertising" directed at the female audience. Furthermore, the style and personality that their advertisements reflect are more classic and formal than those of other perfume brands. It should also be noted, regarding the visual aspects of their advertisements, that importance is attributed to their packaging.

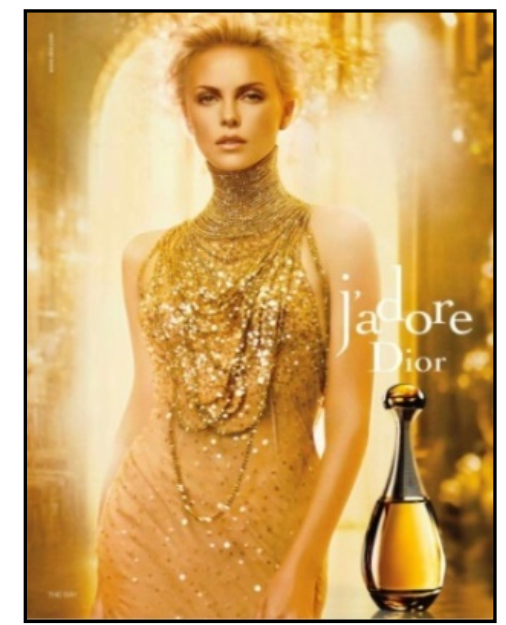

Figure 2. Dior magazine ad. 


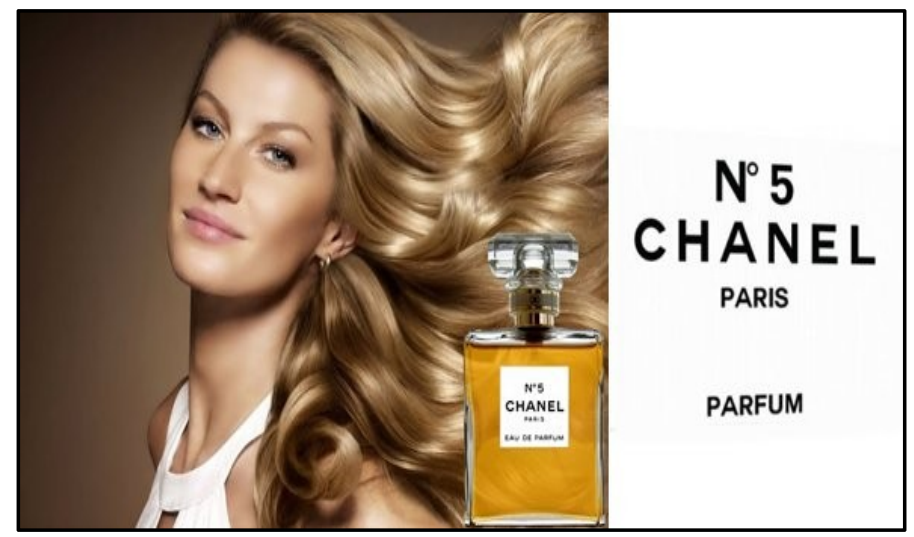

Figure 3. Chanel magazine ad.

As for Calvin Klein and Hugo Boss (see Figures 4 and 5), their creative advertising is marked by a more youthful, modern, and informal tone than those of the other perfumes and their "product advertising" directed towards men is emphasized, positioning them as the more masculine brands.

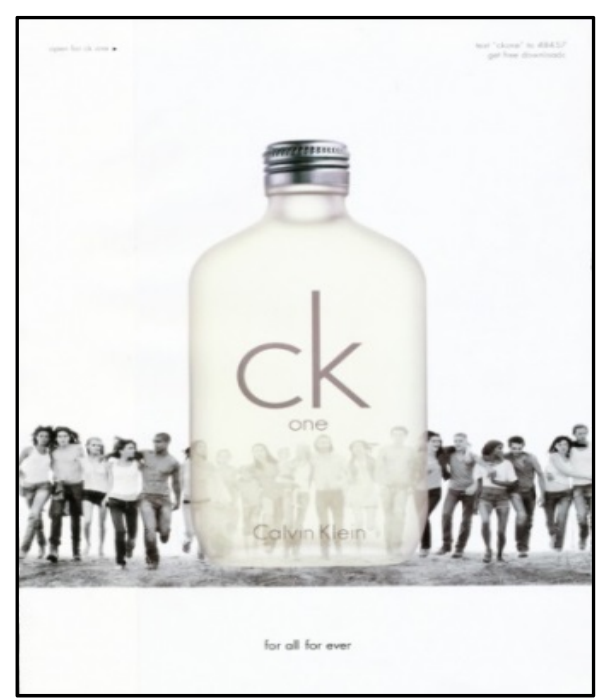

Figure 4. Calvin Klein magazine ad.

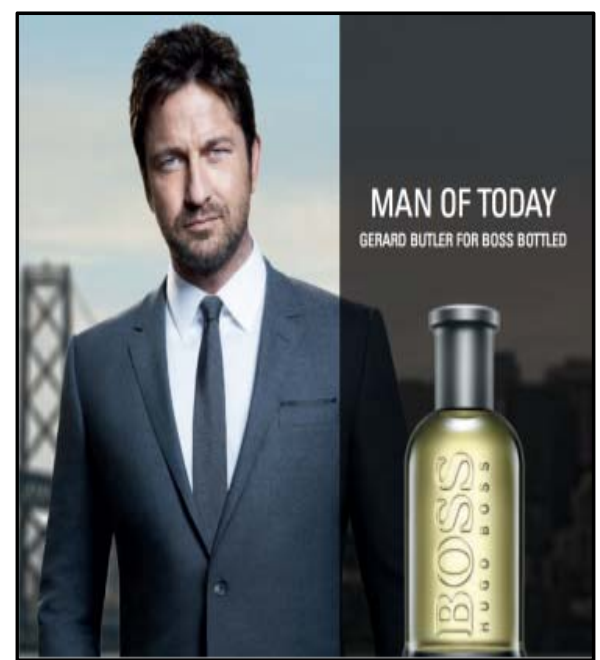

Figure 5. Hugo Boss ad. 
The use of famous personalities is less frequent by these brands than in previous cases (particularly for Calvin Klein) and they tend to use "non-famous" and "more natural” individuals that allow them to get closer to their audience. Their packaging tends to be the most simplistic, resulting in more affordable prices.

Finally, there is the group of brands consisting of Loewe, Armani, Paco Rabanne, and Jean Paul Gaultier (see Figures 6-9) which, according to the previous study, have a less defined positioning in the minds of the consumers. This may be due to the fact that their advertising is more disparate for the different products that they sell on the market and that they tend to opt for "product advertising" where there is no common theme of the corporate brand that accompanies the ads.
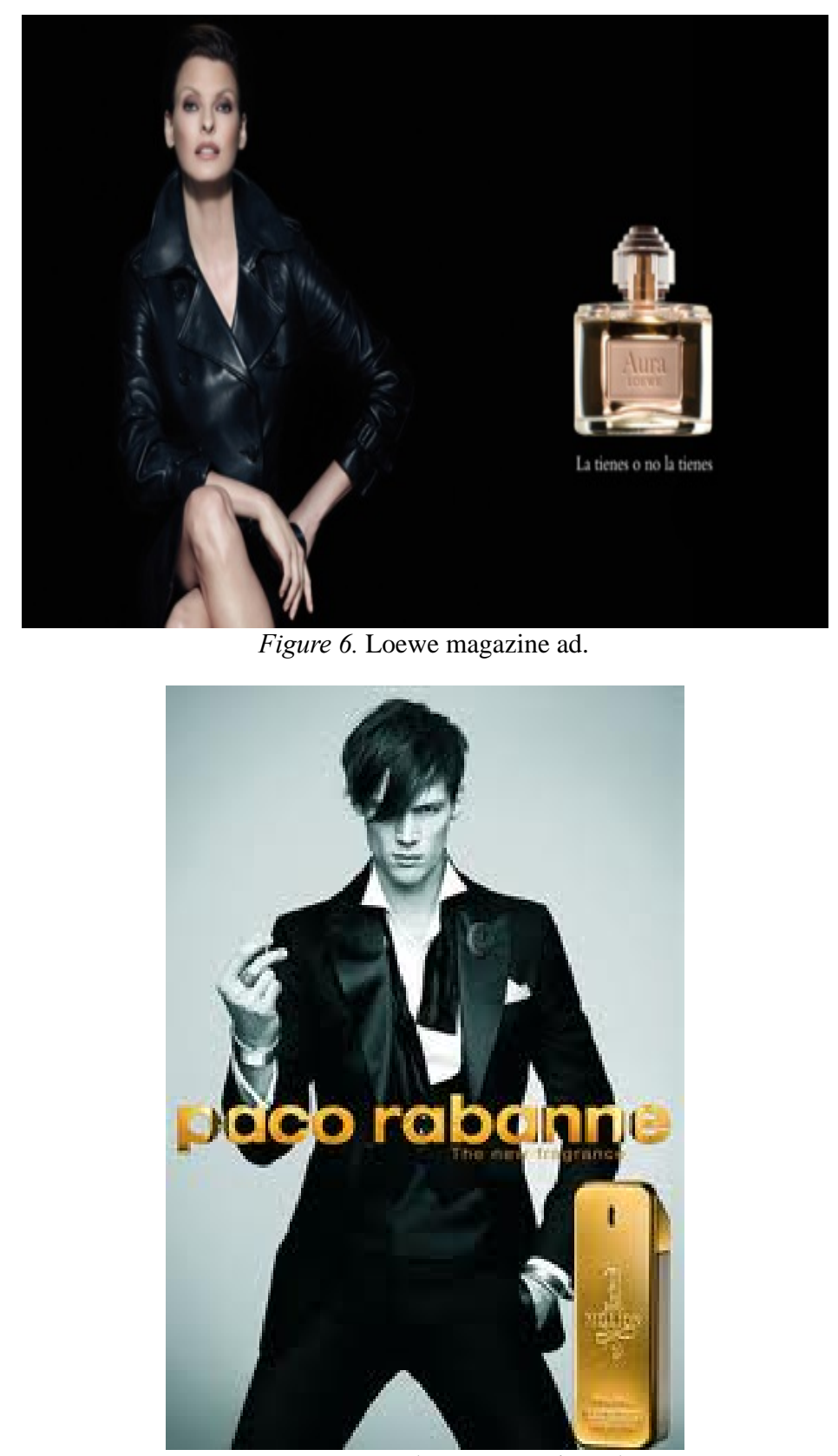

Figure 7. Paco Rabanne magazine ad. 
Generally speaking, and in terms of the positioning obtained in the quantitative study carried out, the brand Loewe is perceived as the most classic and feminine, an image transmitted in many of its advertisements and the brand Rabanne is seen as the most modern and masculine, also as projected in its creative pieces.

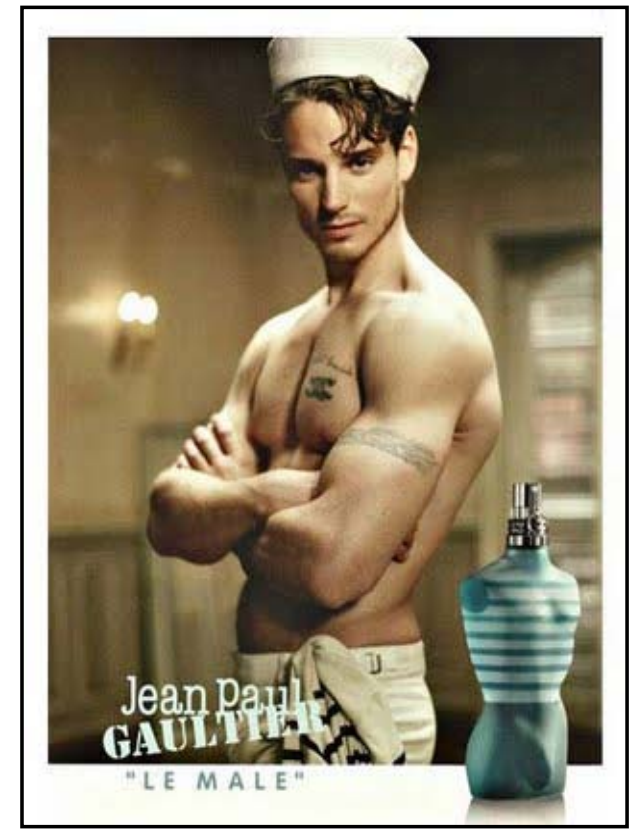

Figure 8. Jean Paul Gaultier magazine ad.

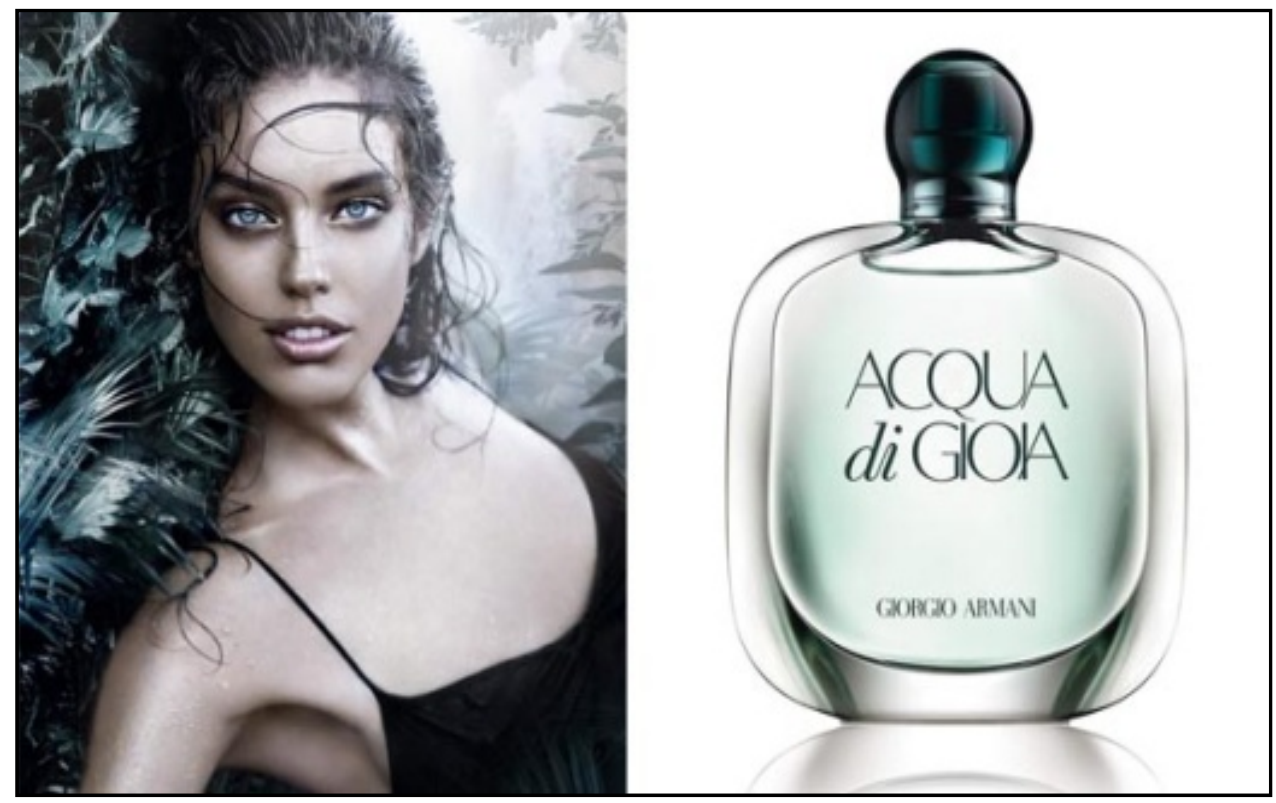

Figure 9. Armani magazine ad.

Finally, Gaultier and Armani (see Figures 8 and 9) are the brands with the most undefined positioning of all of the luxury perfume brands analyzed, according to the previously described study.

When analyzing the advertising of both brands, it is seen that they utilize communication lines and tones that are quite varied, possibly leading to confusion in the perception of their image by the target audience. 


\section{Conclusions, Recommendations, and Future Lines of Study}

It should be recalled that the conclusions made from the study refer to a specific moment of time (when the surveys were conducted) and to a specific competitive context (defined by the brands selected for the study). Furthermore, the study is geographically limited to Spain, and its results may not be generalized to broader areas.

Thus, the results obtained only have a paradigmatic reference value. However, the most relevant conclusion reached from all of the analyses conducted is that the perceived image of each of the studied brands does in fact correspond with the image that is projected in their advertising efforts. This seems to indicate that this advertising is effective in terms of image.

However, there is a clear need for these brands to seek out and develop stronger means of differentiation from their direct competitors in terms of advertising: Chanel as opposed to Dior, and Calvin Klein as opposed to Boss.

As for future lines of study, it may be interesting to carry out the same analysis, while changing the competitive context under study. The competitive context of this study was defined in terms of brand, not product ${ }^{1}$.

It should be recalled that these are the products that are actually acquired by the consumers and that they have their own advertising campaigns. Thus, it appears appropriate to analyze the perceived image of the different products created by the different brands and their suitability to the image projected by their own advertising.

\section{References}

Aaker, D. A. (1996). Cómo construir marcas poderosas. Madrid: Ediciones Gestión.

Aaker, J. L. (1997). Dimensions of brand personality. Journal of Marketing Research, 34(3), 347-356.

Allérès, D. (1990). Luxe: Stratégies-marketing. Paris: Economica.

Ambroise, L., \& Valette-Florence, P. (2010). The brand personality metaphor and inter-product stability of a specific barometer. Recherche et Applications en Marketing, 25(2), 3-28.

Bain \& Company. (2013). Luxury goods worldwide market study. Retrieved from http://www.bain.com/

Braudel, F. (1979). Civilización material, economía y capitalismo. Madrid: Alianza.

Campuzano García, S. (2007). El universo del lujo: Una visión global y estratégica para profesionales y amantes del lujo. Madrid: McGraw-Hill.

Cerviño Fernández, J. (2002). Marcas internacionales: Cómo crearlas y gestionarlas. Madrid: Ediciones Pirámide.

Churchill, G. A. (1979). A paradigm for developing better measures of marketing constructs. Journal of Marketing Research, 16(1), 64-73.

Ciornea, R., Pop, M. D., Bacila, M. F., \& Drule (Tîrca), A. M. (2011). Measuring luxury value perception: Additions to the model of Wiedmann et al. (2007). Marketing From Information to Decision, 4, 94-109.

Colmeiro, M. (1863). Historia de la economía política en España. Madrid: Fundación Banco Exterior.

Danes, J. E., Hess, J. S., Story, J. W., \& Vorst, K. (2012). On the validity of measuring brand images by rating concepts and free associations. Journal of Brand Management, 19(4), 289-303.

Del Rio, A. B., Vazquez, R., \& Iglesias, V. (2001). The effects of brand associations on consumer response. Journal of Consumer Marketing, 18(5), 410-425.

\footnotetext{
${ }^{1}$ In this respect, it is necessary to clarify that in the perfume and cosmetics sector, the term "brand" is used to refer to a generic name of the brand under which different fragrance sub-brands are sold, while the term "product" refers to these sub-brands, that is, the name of the fragrances themselves. Thus, "Armani" is a brand, while "Acqua di Gio" is a product made by that brand.
} 
Díaz-Bustamante, M. (2012). Actitudes y percepciones sobre las fragancias de lujo en España: Investigación en la Comunidad de Madrid (Tesis doctoral inédita, Departamento de Comercialización e Investigación de Mercados, Universidad Complutense de Madrid).

Dichter, E. (1985). What's in an image. Journal of Consumer Marketing, 2(1), 75-81.

Dobni, D., \& Zinkhan, G. M. (1990). In search of brand image: A foundation analysis. Advances in Consumer Research, 17(1), 110-119.

Dolnicar, S., \& Grün, B. (2007). Question stability in brand image measurement: Comparing alternative answer formats and accounting for heterogeneity in descriptive models. Australasian Marketing Journal, 15(2), 26-41.

Dubois, B., Laurent, G., \& Czellar, S. (2001). Consumer rapport to luxury: Analyzing complex and ambivalent attitudes. No. 736, Les Cahiers de Recherche, HEC Paris.

Durgee, J. F., \& Stuart, R. W. (1987). Advertising symbols and brand names that best represent key product meanings. The Journal of Consumer Marketing, 4(3), 15-24.

European Forecasts (Selective Distribution in Spain). Reports 1997-2011. Turnover at manufactures prices. Limited distribution document.

Gardner, B. B., \& Levy, S. J. (1955). The product and the brand. Harvard Business Review, 33(2), 33-39.

Godey, B., Lagier, J., \& Pederzoli, D. (2009). A measurement scale of "aesthetic style” applied to luxury goods stores. International Journal of Retail \& Distribution Management, 37(6), 527-537.

Hsieh, M. H. (2002). Identifying brand image dimensionality and measuring the degree of brand globalization: A cross-national study. Journal of International Marketing, 10(2), 46-67.

Huang, W. (2010). Brand story and perceived brand image: Evidence from Taiwan. Journal of Family and Economic Issues, 31(3), 307-317.

Joyce, T. (1963). Techniques of brand image measurement. In New developments in research (pp. 45-63). London: Market Research Society.

Kapferer, J. (1998). Why are we seduced by luxury brands? Journal of Brand Management, 6(1), 44-49.

Keller, K. L. (1998). Strategic brand management: Building, measuring, and managing brand equity. Upper Saddle River, NJ: Prentice Hall.

Keller, K. L., \& Aaker, D. A. (1992). The effects of sequential introduction of brand extensions. Journal of Marketing Research, 29(1), 35-50.

Kotler, P., \& Keller, K. L. (2012). Dirección de marketing (14th ed.). México: Pearson Editorial.

Koubaa, Y. (2008). Country of origin, brand image perception, and brand image structure. Asia Pacific Journal of Marketing and Logistics, 20(2), 139-155.

Letichevsky, S. S. (2002). Bernardo de Mandeville y la función del lujo. El catoblepas, 5, 21-23.

Low, G. S., \& Lamb, C. W. (2000). The measurement and dimensionality of brand associations. The Journal of Product and Brand Management, 9(6), 350-370.

Martinez, E., \& De Chernatony, L. (2004). The effect of brand extension strategies upon brand image. Journal of Consumer Marketing, 21(1), 39-50.

Park, S. H. (2009). The antecedents and consequences of brand image: Based on Keller's customer-based brand equity (Ph.D., The Ohio State University). ProQuest Dissertations and Theses (304985734).

Sanz de la Tajada, L. A. (1994). Integración de la identidad y la imagen de la empresa: Desarrollo conceptual y aplicación práctica. Madrid: Escuela Superior de Gestión Comercial y Marketing, ESIC.

Smith, A. (1776). Edición de Cannan, Edwin (1997). Estudio preliminar de Gabriel Franco. Investigación sobre la naturaleza y causas de la riqueza de las naciones. Mexico: Fondo de cultura económica.

Stanpa (Spanish Cosmetic Toiletry and Perfumery Association). (2013). General statistics of the perfumery and cosmetics sector in Spain. Reports 2009-2013. Turnover at manufactures prices. Limited distribution document.

Stern, B., Zinkhan, G. M., \& Jaju, A. (2001). Marketing images construct definition, measurement issues, and theory development. Marketing Theory, 1(2), 201-224.

Veblen, T. (1899). La teoría de la clase ociosa. Madrid: Alianza Editorial.

Vickers, J. S., \& Renand, F. (2003). The marketing of luxury goods: An exploratory study - three conceptual dimensions. The Marketing Review, 3(4), 459-478.

Vigneron, F., \& Johnson, L. W. (2004). Measuring perceptions of brand luxury. The Journal of Brand Management, 11(6), 484-506. 
Wiedmann, K. P., Hennigs, N., \& Siebels, A. (2007a). Measuring consumers' luxury value perception: A cross-cultural framework. Academy of Marketing Science Review, 7(7), 333-361.

Wiedmann, K. P., Hennigs, N., \& Siebels, A. (2007b). Understanding and measuring luxury value: A multidimensional model of consumers’ luxury perception. American Marketing Association, 7, 393-395.

Wiedmann, K. P., Hennigs, N., \& Siebels, A. (2009). Value-based segmentation of luxury consumption behavior. Psychology \& Marketing, 26(7), 625-651.

Zaichkowsky, J. L. (1985). Measuring the involvement construct. Journal of Consumer Research, 12(3), 341-352.

Zinkhan, G. M., Locander, W. B., \& Leigh, J. H. (1986). Dimensional relationships of aided recall and recognition. Journal of Advertising, 15(1), 38-46. 